\title{
Effect of eight weeks of high intensity interval training and crocin consumption on the apoptotic genes expression in the liver tissue of male rats under chronic doxorubicin induction
}

\author{
Mahraz Moradi ${ }^{1}{ }^{1}, \underline{\text { Saeid Shakerian }}{ }^{2}{ }^{2}$, Masoud Nikbakht ${ }^{\left(D^{2}\right.}$
}

\begin{abstract}
Background and Aims: The use of doxorubicin (Dox) in chemotherapy has irreversible effects on liver tissue. The role of physical activities and antioxidants consumption has not yet been fully understood in the mechanism of apoptosis induced by Dox. Therefore, the present study aimed to investigate the effect of High Intensity Interval Training (HIIT) and crocin consumption on liver tissue apoptosis in male rats under chronic Dox induction.
\end{abstract}

Materials and Methods: In this experimental study, 40 male Wistar rats with mean weight of $200 \pm 20 \mathrm{~g}$ and mean age of 8 weeks were divided into five groups, including healthy control, Dox ( $2 \mathrm{mg} / \mathrm{kg}$ in $7 \mathrm{doses})$, Dox+crocin $(10 \mathrm{mg} / \mathrm{kg})$, Dox $+\mathrm{HIT}$, and Dox + HIIT+crocin. The training program included running on the treadmill for 8 weeks, 5 days a week, at 2-minute intervals with an intensity of $80-90 \%$ of the maximum speed. Liver biopsy was performed to assess the fibrosis and expression of Bax and Bcl-2 genes using RTPCR method $48 \mathrm{~h}$ after the last training session. The statistical analysis was conducted through one-way ANOVA, and a p-value of $\leq 0.05$ was considered statistically significant.

Results: Treatment with Dox significantly increased Bax expression, compared to $\mathrm{Bax} / \mathrm{Bcl}$-2. Moreover, it decreased $B c l-2$ expression in the liver tissue of the patient groups $(\mathrm{P}=0.001)$. In contrast, crocin and the combination of exercise and crocin decreased Bax expression, compared to Bax/Bcl-2 and increased $\mathrm{Bcl}-2$ expression in experimental groups, compared to Dox group $(\mathrm{P}=0.001)$.

Conclusion: The results indicated that the HIIT combined with the consumption of crocin had a significant effect on the decrease of apoptosis in the liver tissue of male rats subjected to chronic doxorubicin injection.

Keywords: Apoptosis, Crocin, Doxorubicin, High-Intensity Interval Trainings, Liver

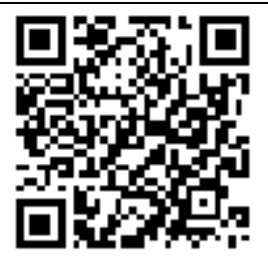

Citation: Moradi M, Shakerian S, Nikbakht M. [Effect of eight weeks of high intensity interval training and crocin consumption on the apoptotic genes expression in the liver tissue of male rats under chronic doxorubicin induction]. J Birjand Univ Med Sci. 2020; 27(4): 323-335. [Persian]

DOI http://doi.org/10.32592/JBirjandUnivMedSci.2020.27.4.101

Received: January 6, $2020 \quad$ Accepted: April 24, 2020

\footnotetext{
${ }^{1}$ Department of Sport Physiology, Shoushtar Branch, Islamic azad University, Shoushtar, Iran

2 Department of Exercise Physiology, Factuly of Sport Sciences, Shahid Chamran University of Ahvaz, Ahvaz, Iran
}

Corresponding author: Department of Exercise Physiology, Factuly of Sport Sciences, Shahid Chamran University of Ahvaz, Ahvaz, Iran

Tel: +986133333631

Fax: +986133333631

Email: sashakeryan@gmail.com 


\section{اثر هشت هفته تمرين تناوبى شديد و مصرف كروسين بر بيان ثنهاى آبويتيك بافت كبد رتهاى نر تحت القاء مزمن دوكسوروبيسين}

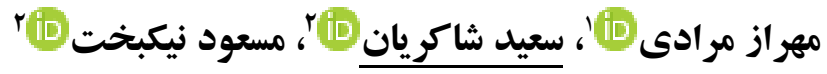

\section{جكيده}

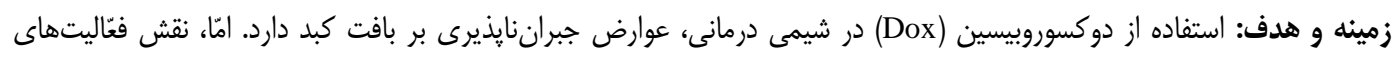

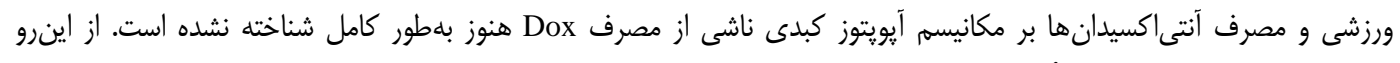

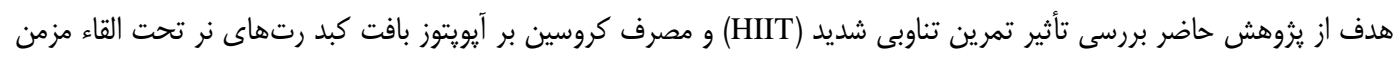

$$
\text { Dox }
$$

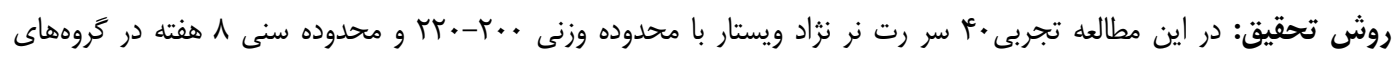

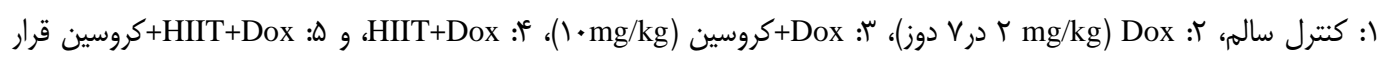

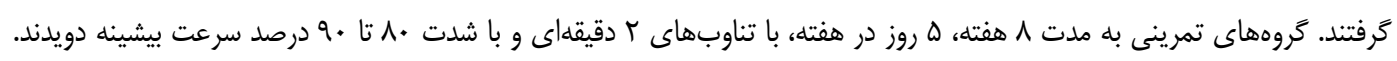

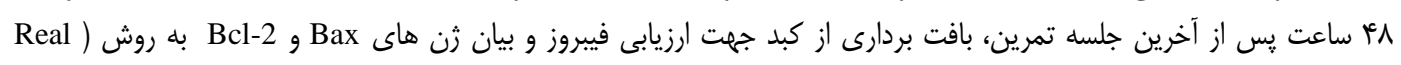
(time-PCR

$$
\text { بررسى شدند. }
$$

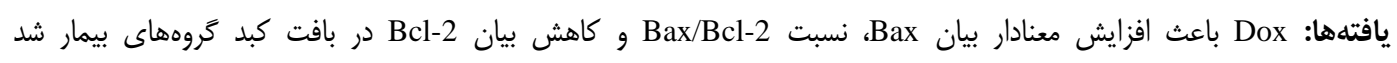

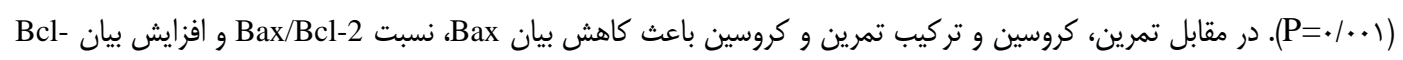

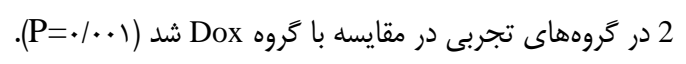

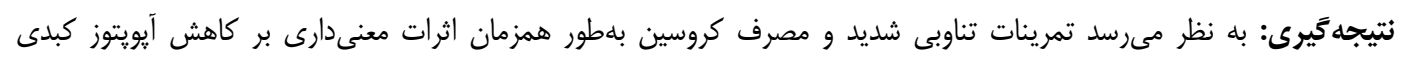

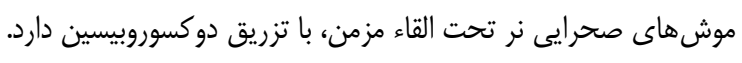

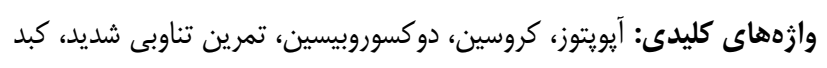

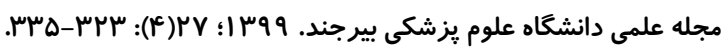

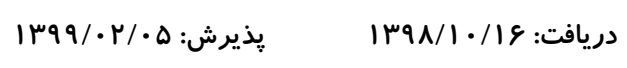

' بكروه فيزيولوزى ورزشى، واحد شوشتر، دانشكاه آزاد اسلامى، شوشتر، ايران

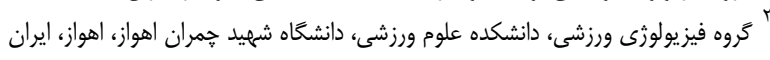

نويسنده مسئول: كروه فيزيولوزى ورزشى، دانشكده علوم ورزشى، دانشكاه شهيد خمران اهواز، اهواز، ايران

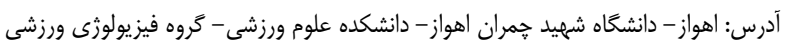

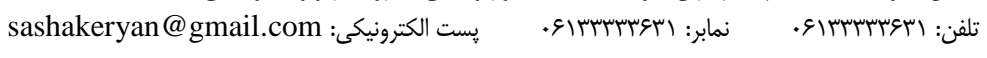


اندويلاسميك، آزادساز ريبوزوم ها و تجزيـه سـلول بــه اجسـام

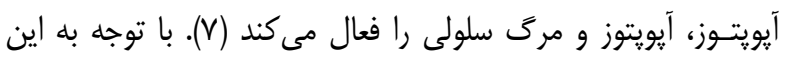

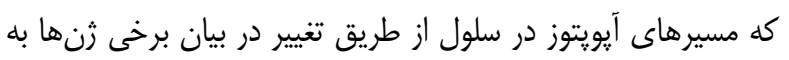
ويثه نسبت Bcl-2 /Bax تنظيم مىشود، مقايسه ميزان بيان زن رئن

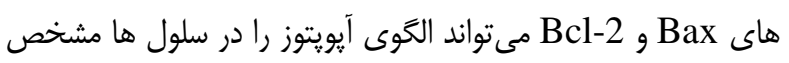

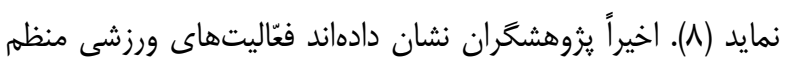

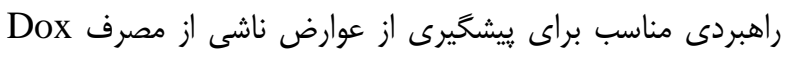

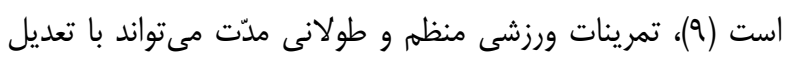
استرس اكسيداتيو، رويكردى مناسب جهت كاهش سميت Dox باشد (َّ). با اين وجود نوع و شدّت تمرين عاملى روبكردي مهنم در نتايج مىباشد، به كونهاى كه هشت هفته تمرين شنا سـبب افزايش

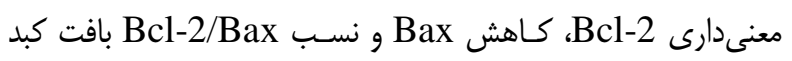

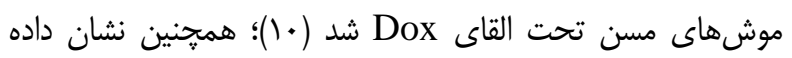

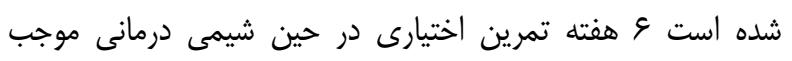

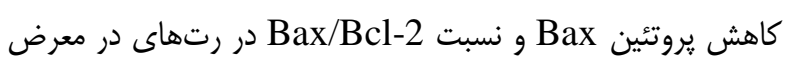

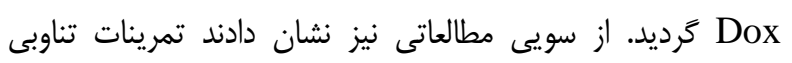

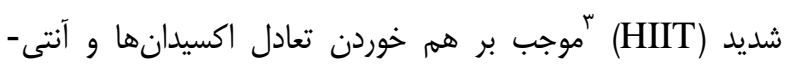

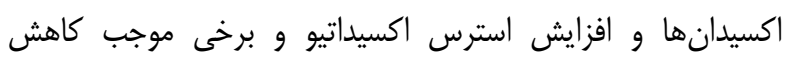

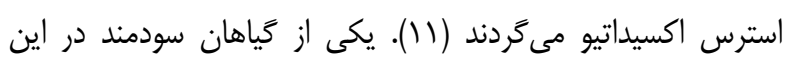
زمينه، زعفران مىباشد كه داراى خواص و كاربردهاى دارويى و

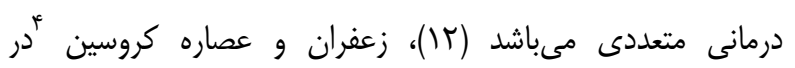

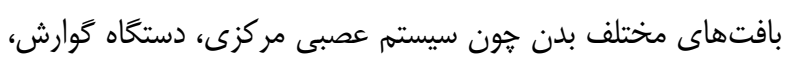

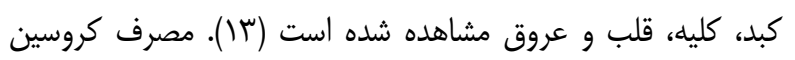
موجب افزايش سطوح P53 و كاهش Bcl-2

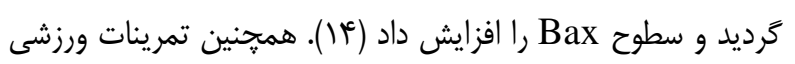

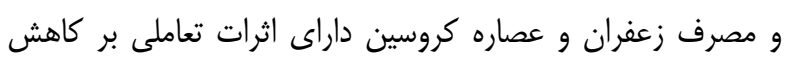

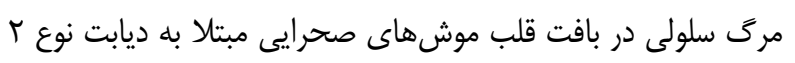
و بهبود شاخصهاى متابوليكى در محيطهاى Invivo و و Invitro (10) بود. با اين وجود به نظر مىرسد مطالعات در حيطه تأثير

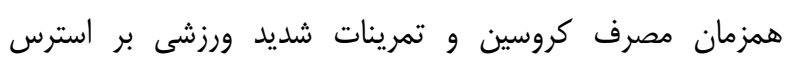
اكسيداتيو ناشى از Dox هنوز بهطوركامل شناخته نشده است،

${ }_{4}^{3}$ High-intensity interval training

${ }^{4}$ Crocin

\section{مقاله}

در حال حاضر بيمارى سرطان از بزركترين مشكلات سلامت جهانى و دومين عامل مرگ و مير در سطح جهان است (اول). امّا؛

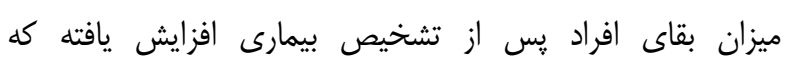

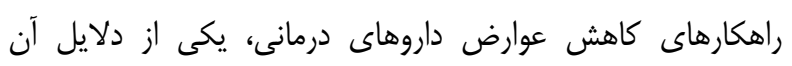

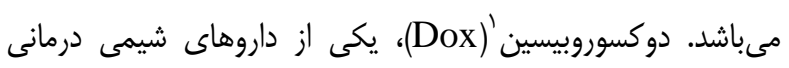

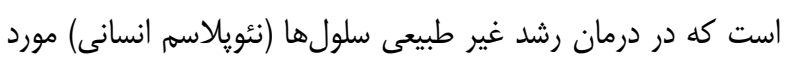

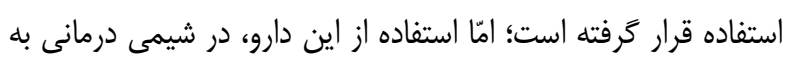
همراه سميت وابسته به دوز در بافتهاى غير هدف مانند كبد محدود

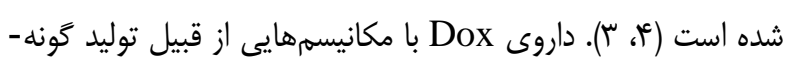

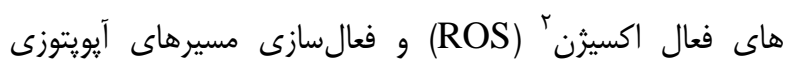
موجب ازهمَسيختىى DNA سلولهاى سرطانى مى شود و و در بافتهاى سالمى همجون كبد با اختلال در آنزيمهاى كبدى آنسي،

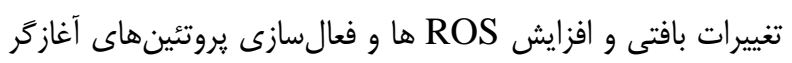

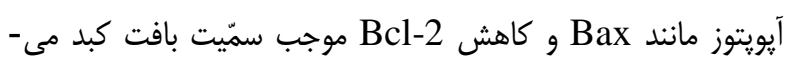

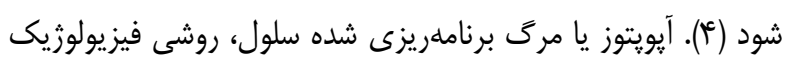

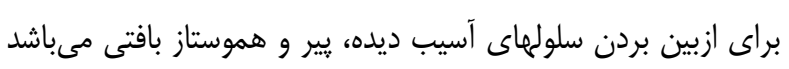
كه از دو مسير بيرونى و درونى اتفاق مى افتد (ه). هركّونه اختلال

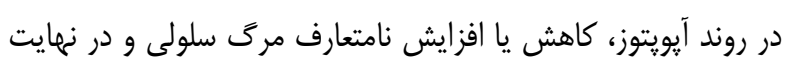

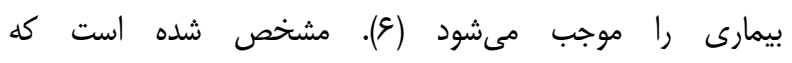
دوكسوروبيسين، عمدتاً از مسير داخلى سبب القاى آيويتوز مىباشد.

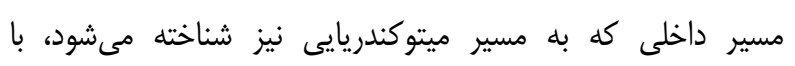

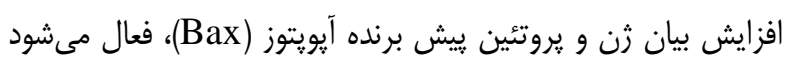

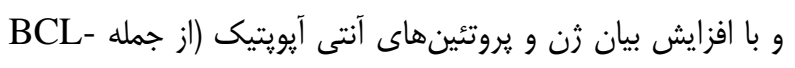

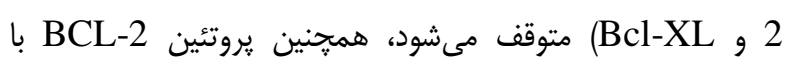

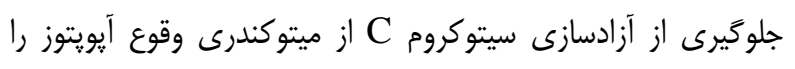

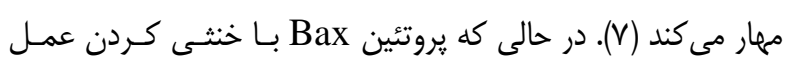

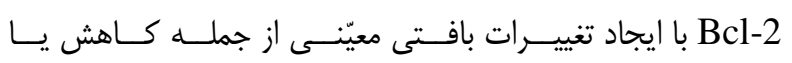

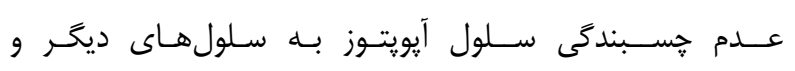

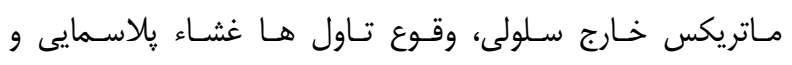

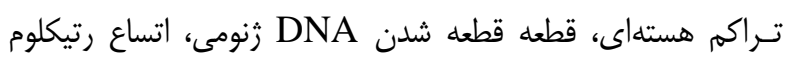

${ }^{1}$ Doxorubicin

${ }^{2}$ Reactive oxygen Species 
كتامين و زايلازين (به ترتيب •و و •1 1mg/kg) بلهورت تزريق صفاقى بيهوش شدند، و يس از شكافتن حفره شكمى، بافت كبد بله

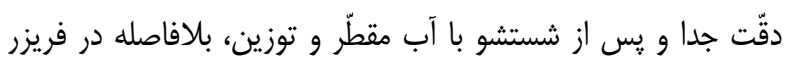

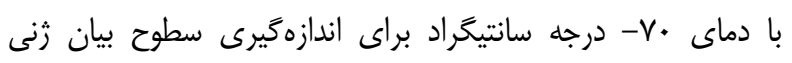
متغيرها قرار كرفتند.

\section{يروتكل تمرين}

جهت انجام تمرينات ورزشى كَروهاى تمرين به مدّت هشت تمرين هفته، هنج جلسه در هفته تمرينات تناوبى را انجام دادند. تمرينات تناوبى شديد(درصد از سرعت بيشينه) در اين تحقيق بدين صورت

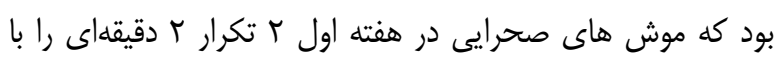

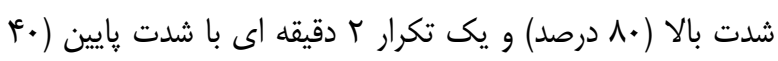

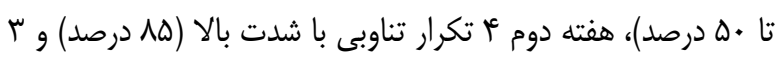

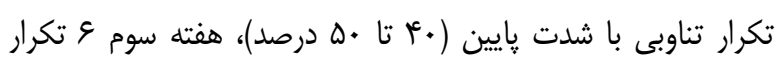

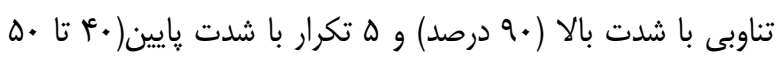

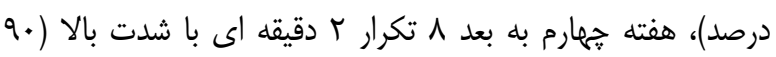
درصد) و V تكرار با شدت پايين (• أ تا •ه درصد) را انجام دادند.

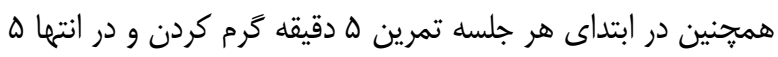

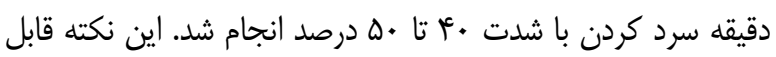

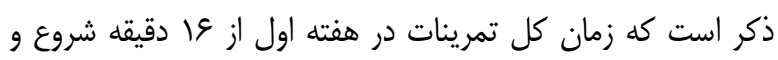

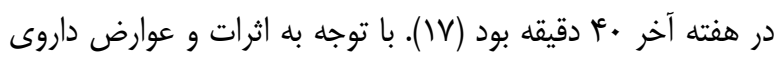
دوكسوروبيسن بر عملكرد موشهاى صحرايى، شدّت آن تعديل

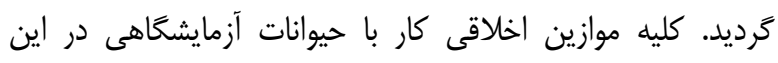
تحقيق بر اساس موازين اخلاقى مصوب با استانداردهاى اخلاقى در

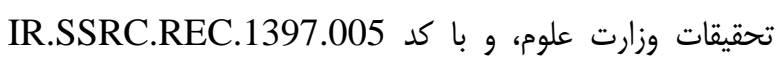
رعايت گرديد.

\section{نحوه مصرف كروسين}

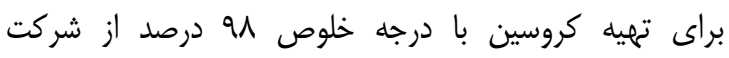

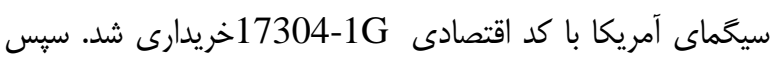

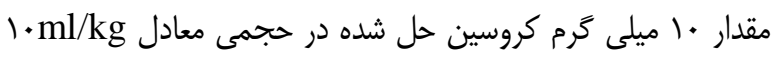

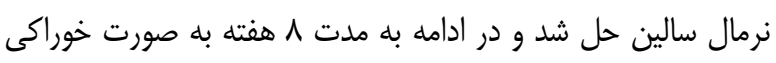

همجنين با توجه به عوارض جانبى جبران نايذير اين دارو انجام

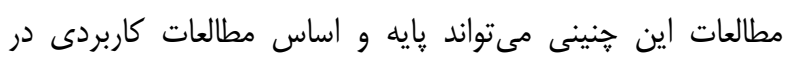

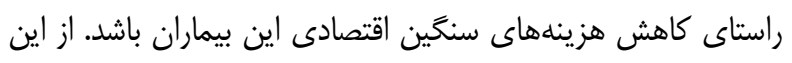
رو مطالعه حاضر با هدف بررسى تاثير هشت هفته تمرين تناوبى رئسئ

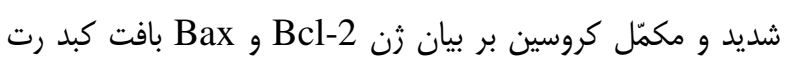
هاى نر تحت القاء مزمن Dox انجام شد.

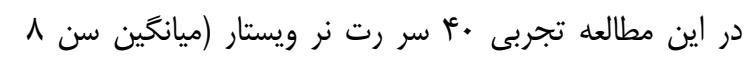

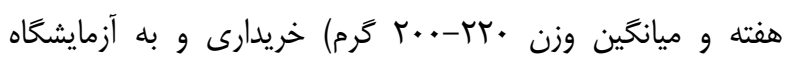

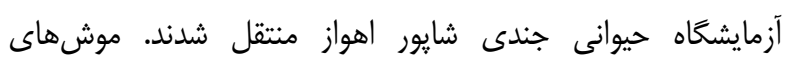
صحرايى به مدّت دو هفته جهت سازگارى در محيط آزمايشعاه

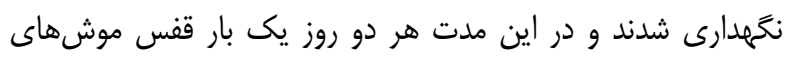

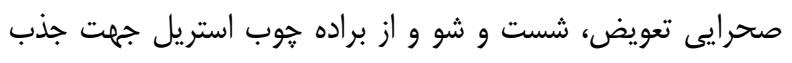

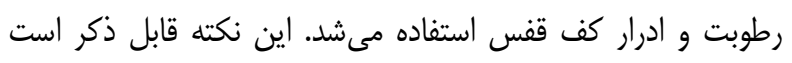
كه در تمام دوره تحقيق موشهاى صحرايى در شرايط استاندارد

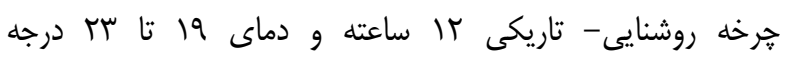

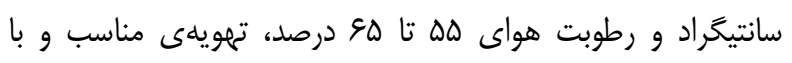

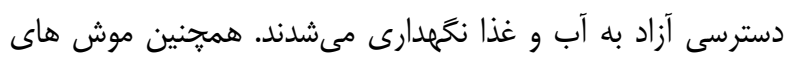

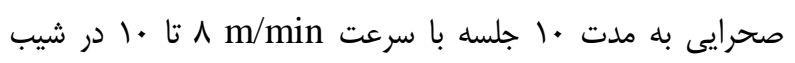
صفر درجه و به مدت ه تا ما دقيقه با هدف آشنايى با نواركردان

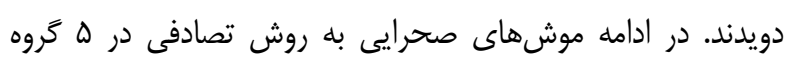

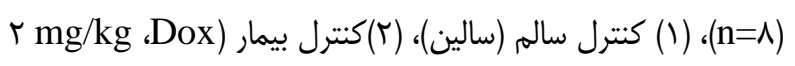

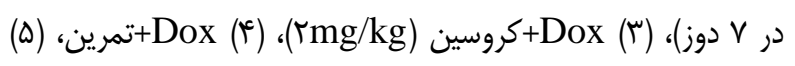

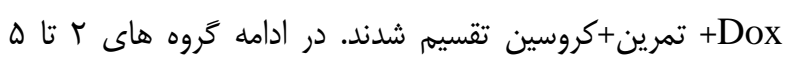

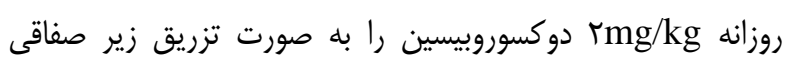

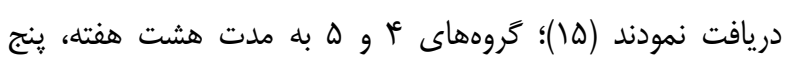

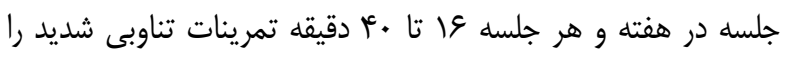

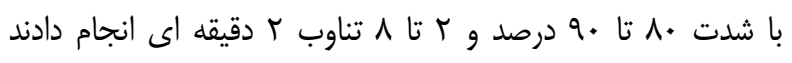
(IV)

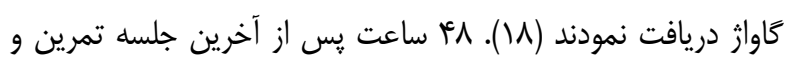

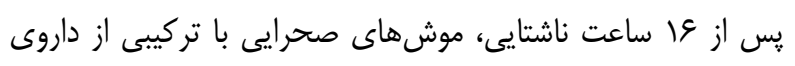


ريخته شد و به مدّت ا دقيقه مخلوط گَرديد. پِ از ع M ساعت

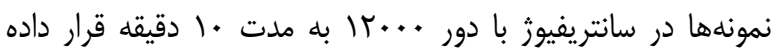

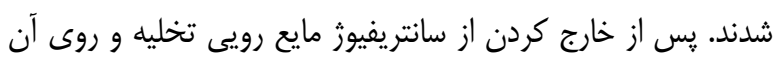

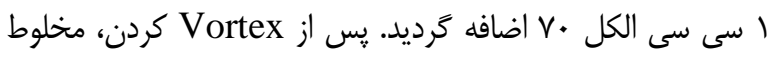

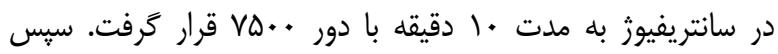

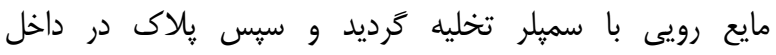

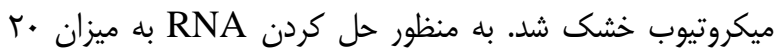

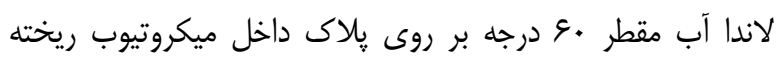

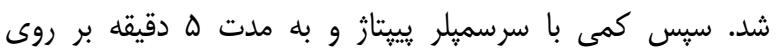

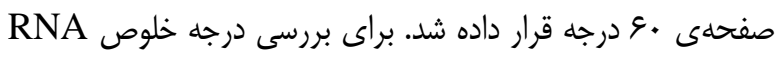

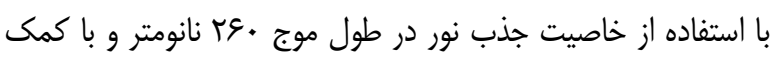
رابطهى زير مىتوان درجه خلوص نمونهى RNA بررسى كرديد $\mathrm{C}(\mu \mathrm{g} / \mu \mathrm{l})=\mathrm{A} 260 \times \varepsilon \times \mathrm{d} / 1000$ در ادامه RNA استخراج شده تا زمان استفاده در دماى •^- قرار كرفت. - مر

سنتز

سنتز cDNA بر اساس دستورالعمل موجود در كيت فرمنتاز

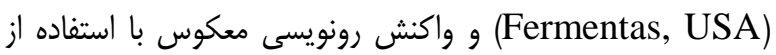
آنزيم

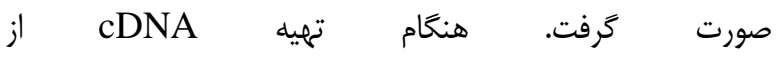
نمونه تخليص شده يس از قرائت جذب، حجمى شامل ....

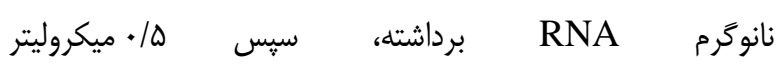
RandomHexamers يرايمر براى شروع سنتز cDNA استفاده مى شود)، ه/• ميكروليتر

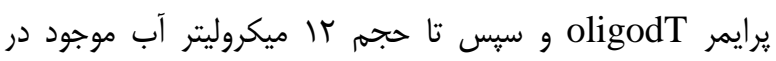

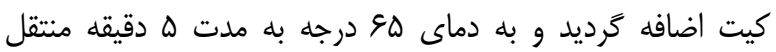
كَرديد و سِّ به مدّت r دقيقه بر روى يخ قرار گَرفت. در مرحله

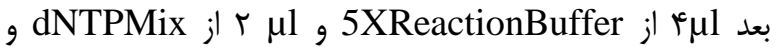
ز $1 \mu 1$, RiboLockRNaseInhibitor ز $\mid \mu 1$ 90 به تركيب قبل كه براى ه دقيقه در دماى RevertAidRT

\footnotetext{
${ }^{1}$ Deoxyribonucleotide
}

(كاواز) به موش هاى صحرايى خورانده شد. اين نكته قابل ذكر است كه جهت بررسى اثرات حلال كروسين و القا اثرات كاواز، كروه هاى كنترل سالم و بيمار هم به همان ميزان نرمال سالين، بهصورت

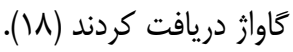

\section{تزريق دوكسوروبيسين}

براى تزريق داروى دوكسوروبيسين اين دارو از شركت بلزيكى دورويى تروين Ebeve

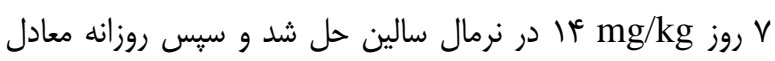

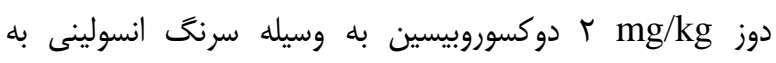
صورت زير صفاقى تزريق شد. با توجه به اثرات احتمالى ناشى از

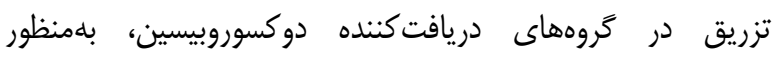
يكسان سازى شرايط براى همه آزمودنىها و خنثى نمودن اثر تزريق، كروه كنترل سالم نيز به همان ميزان سالين (سديم كلرايد 9 ــ

$$
\text { درصد) دريافت كرد (ع) كنرل }
$$

\section{روش اندازهَيرى متغيرها روش استخراج RNA} براى استخراج RNA طبق يروتكل شركت سازنده كيت

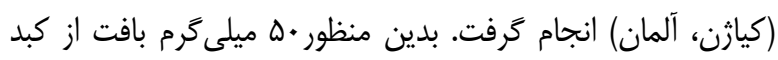
در نيتروثن مايع خشك و پِ از كوبيدن در آونخ استريل، درون

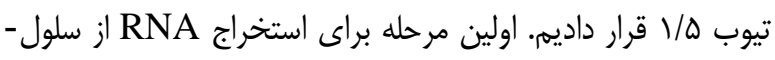
هاى حيوانى از بين بردن ديواره ى سلول ها با كمى يكى بافر ليز

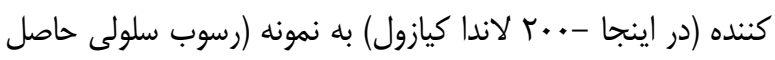

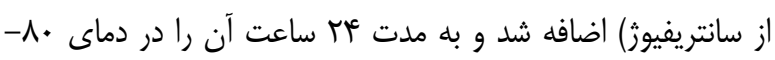

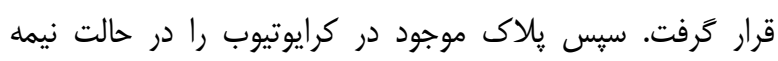

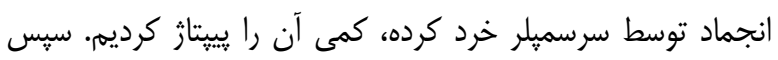
به نمونه حدود ..1 لاندا كلروفرم اضافه شد تا سلولها ليز شود.

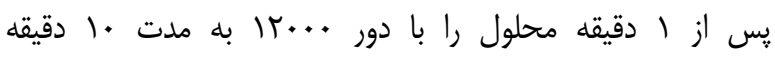

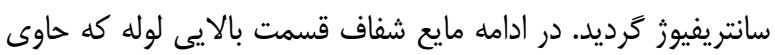

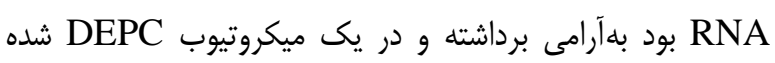

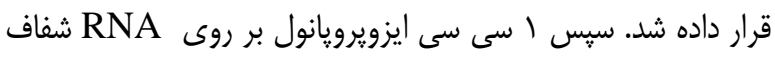




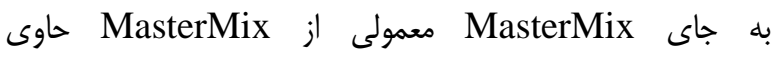

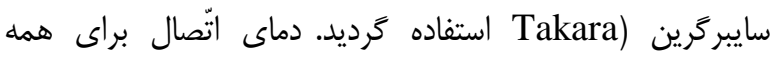

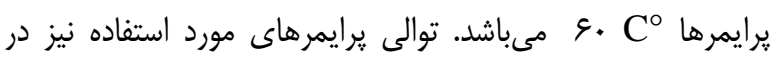
جدول شماره ا نشان داده شده است. يس از اتمام فتّاليت دستخاه و مشاهده نمودارها مبنى بر افزايش

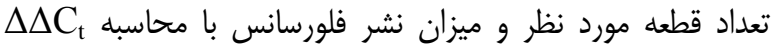

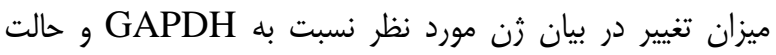
كنترل كه فاقد محيطهاى تمايزى است، سنجيده شد.
قرار گرفته بود، اضافه شد. سِيس تركيب ابتدا به مدّت ه دقيقه در

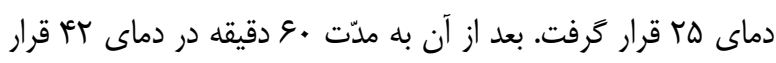

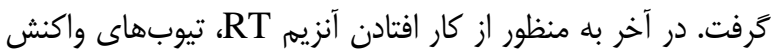
به مدت ه دقيقه در دماى •V درجه سانتى گراد قرار داده شد. آماده شده جهت انجام RDNA

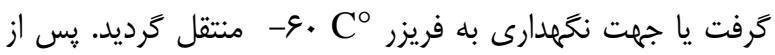
بهينهسازى واكنش، CDNA مربوط به گروههاى مورد آزمايش مطابق جدول زمانى Y- V- تحت واكنش RT-PCR قرار كرفتند. اصول انجام RT-PCR مشابه PCR معمولى بود با اين تفاوت كه

جدول ا - توالى يرايمرهاى رفت و برَشت زنهاى مورد نظر براى واكنش Real-time PCR

\begin{tabular}{|l|l|l|}
\hline زن & Forward برايمر & Reverse \\
\hline GAPDH & 5'-ACCCAGAAGACTGTGGATGG-3' & 5'-TTCTAGACGGCAGGTCAGGT-3' \\
\hline Bax & 5'-GCTGGACATTGGACTTCCTC-3' & 5'-ACCACTGTGACCTGCTCCA-3' \\
\hline Bcl-2 & 5'-GCTGGACATTGGACTTCCTC-3' & 5'-GCTGGACATTGGACTTCCTC-3' \\
\hline
\end{tabular}

$$
\begin{aligned}
& \text { Ratio } \left.\left.=\mathrm{E}^{-\{(\Delta \mathrm{CT} \text { case }}{ }^{-}{ }_{\text {control }}^{(\Delta \mathrm{CT}}\right)\right\} \quad \Delta \mathrm{CT}=\mathrm{CT}_{\text {target }}-\mathrm{CT}_{\text {reference }} \\
& \text { اگر بازده PCR را كامل در نظر بحيريمم فرمول زير قابل استفاده است: } \\
& \text { Ratio } \left.\left.\left.=2^{-\{(\Delta \mathrm{CT} \text { case }}\right)^{-(\Delta \mathrm{CT}} \text { control }\right)\right\}
\end{aligned}
$$

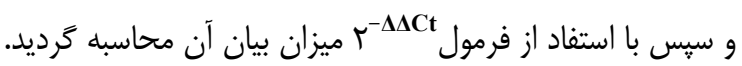

ميكروسكوٍ Labomed، بررسى شدند. تفسير تصاوير با نرم افزار

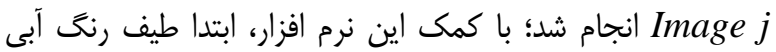
مربوز به نواحى فيبروز انتخاب و سيس ساير بيكسلهاى تصوير

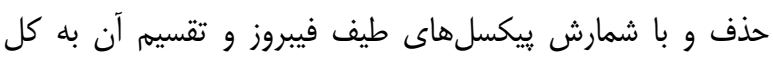

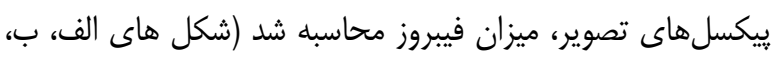

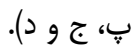

\section{روش تجزيه و تحليل آمارى}

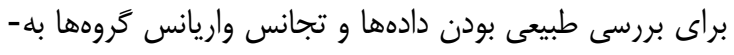

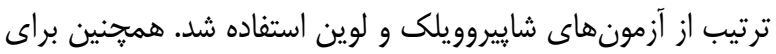
تجزيه و تحليل دادها از آزمون آناليز واريانس يكسطرفه همراه با بان

\section{روش تهيه لام و رنغَ آميزى تريكروم ماسون}

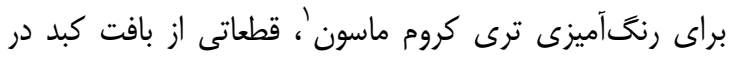

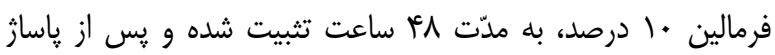
بافتى، برشهايى با ضخامت ه ميكرون، توسط ميكروتوم دوارمدل

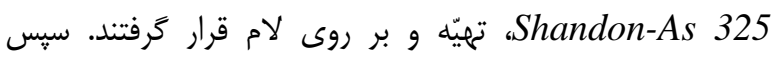
لامها يس از رنخَآميزى به روش ترى كروم ماسون مورد مطالعه

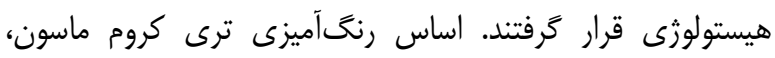
شناسايى رشتهاى كلازنى مىباشد كه به رنغ آنى آبى مشاهده

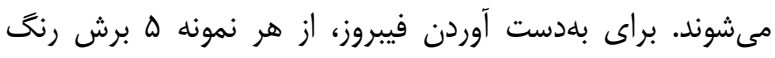

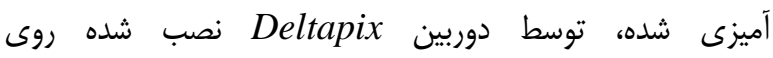

1 Trichrome Masson 


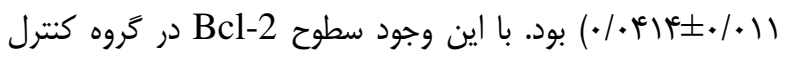

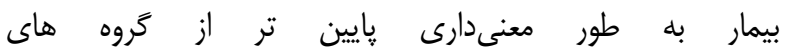

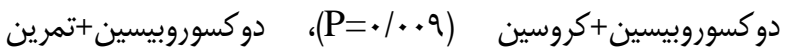

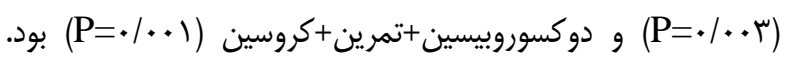
همجنين سطوح Bcl-2 در گروه هاى دوكسوروبيسين+كروسين (P=•/.1) معنى دارى كمتر از گروه دوكسوروبيسين+تمرين+كروسين بود. با اين

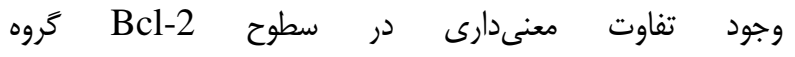
دوكسوروبيسين+كروسين و دوكسوروبيسين+تمرين مشاهده نشد نشات (نمودار r) ( (P=./99)

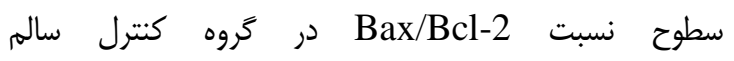

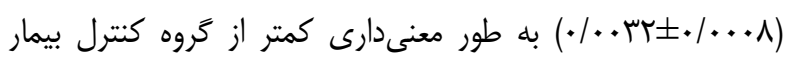

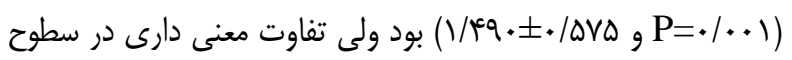
نسبت Bax/Bcl-2 در گروه كنترل سالم در مقايسه با بال

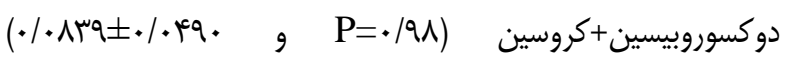

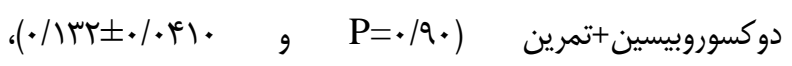

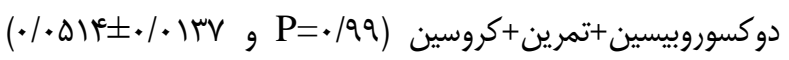
مشاهده نشد. با اين وجود سطوح نسبت Bax/Bcl-2 دروسين

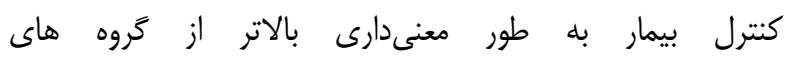

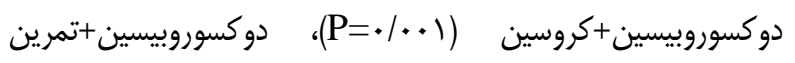

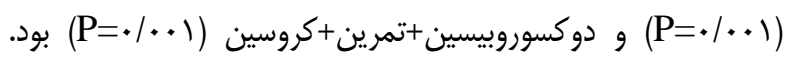
امّا تفاوت معنىدارى در سطوح نسبت Bax/Bcl-2 در مركورو

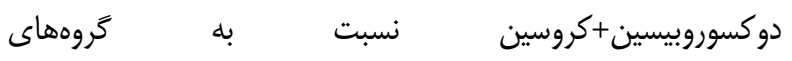

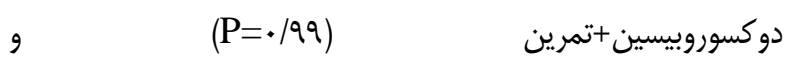
دوكسوروبيسين +تمرين +كروسين (P=/99) مشاهده نشد. همجنين

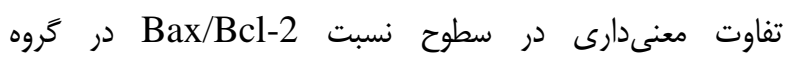
دوكسوروبيسين+تمرين

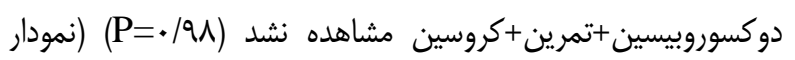
(r)
مقايسه ميانخينهاى توكى در نرم افزار SPSS ويرايش آ استفاده

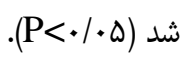

\section{هافته ها}

تجزيه و تحليل دادهها نشان داد كه تفاوت معنىدارى در بيان

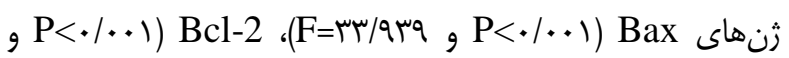
(F=rع/ץq و بافت كبد موش هاى صحرايى گَروههاى تحقيق وجود دارد.

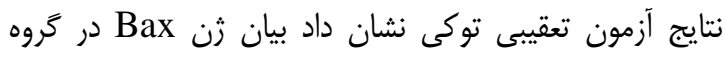

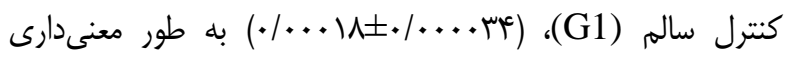

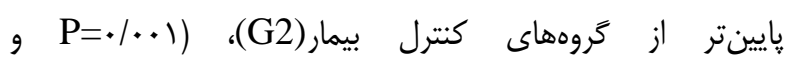

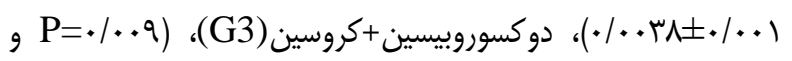

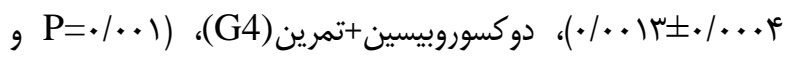

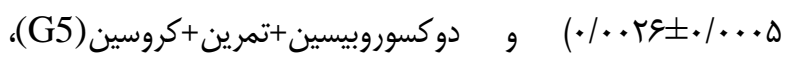
(1) Bax

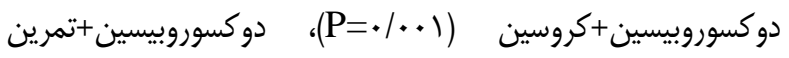

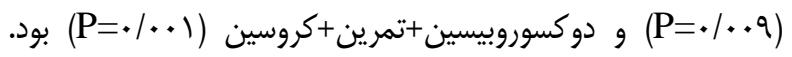
همجنين سطوح بيان زنى Bax در خروه دوكسوروبيسين+كروسين

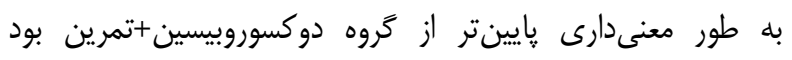

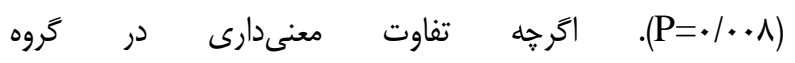

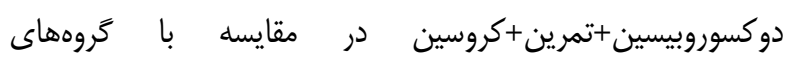

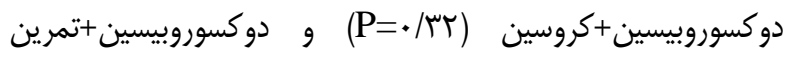
(P=•/c•)

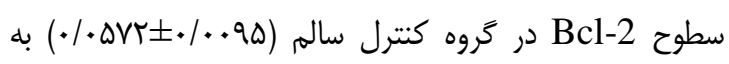

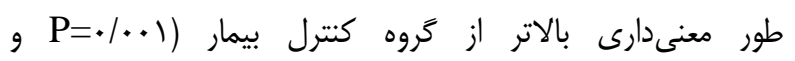
عq. •|•

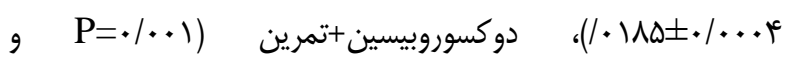

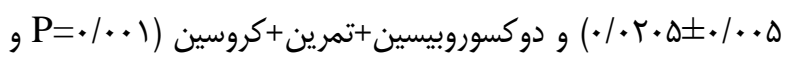




\subsection{6}

0.005

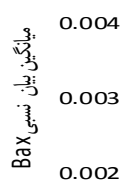

0.001

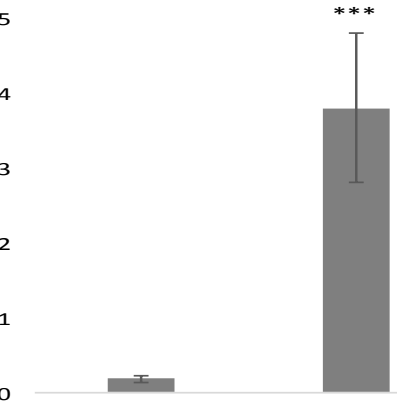

G 1

G2

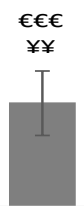

G3

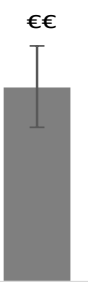

G4

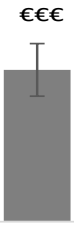

G5

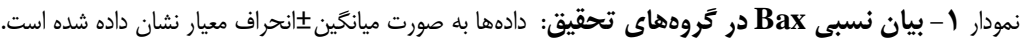

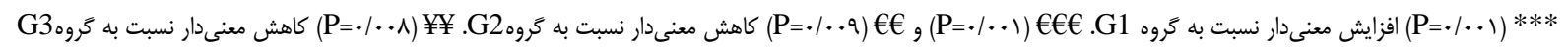

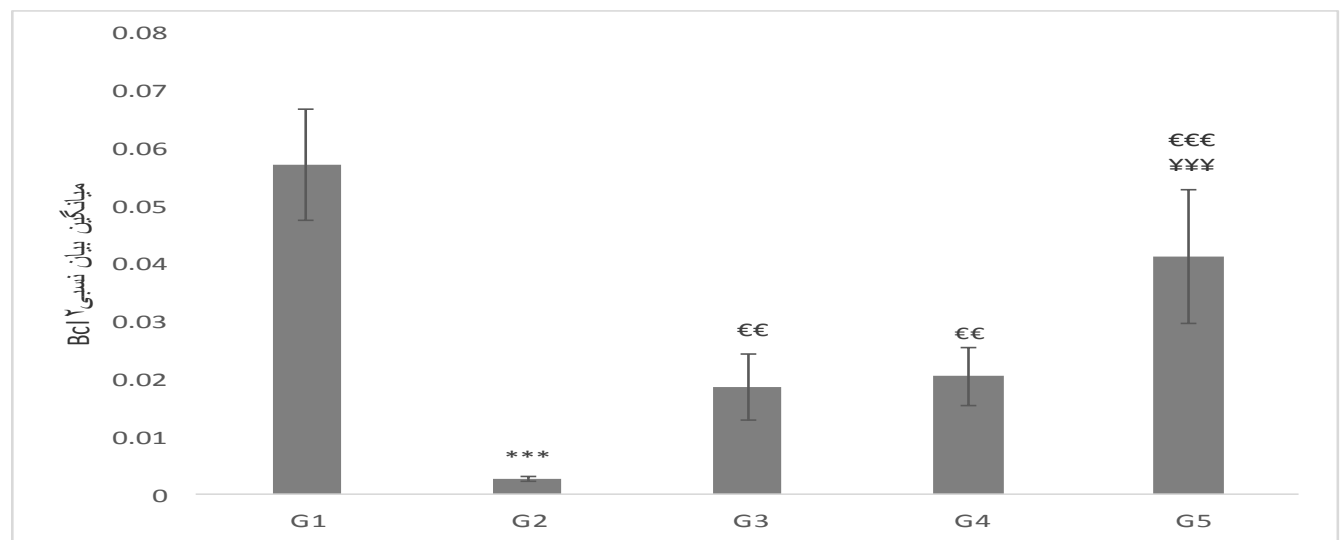

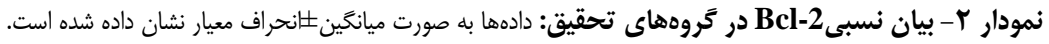

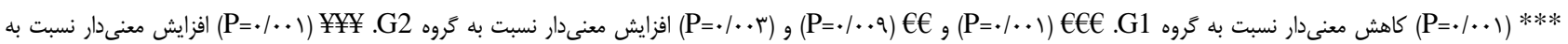
$\mathrm{G} 3$ و $\mathrm{G} 4 \mathrm{~s}$

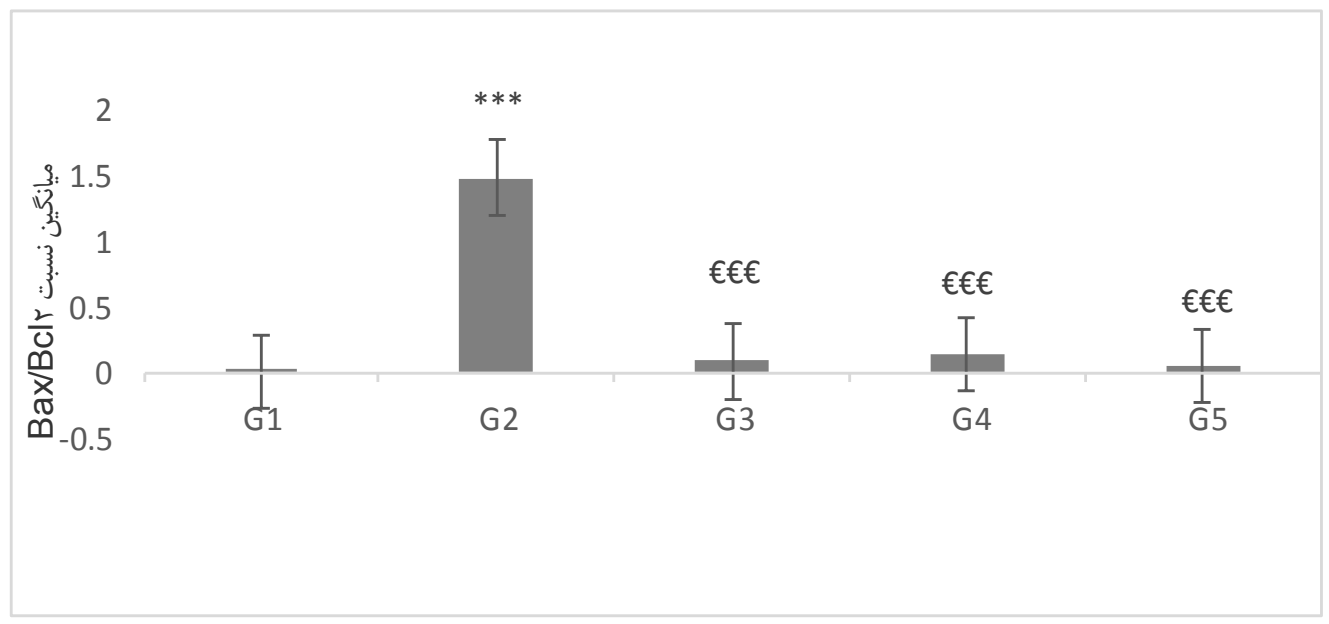

نمودار بـ - بيان Bax/Bcl-2 در تروههاى تحقيق: دادهها به صورت ميانكَين لانحراف معيار نشان داده شده است.

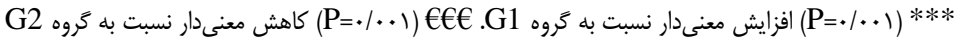




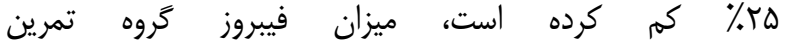

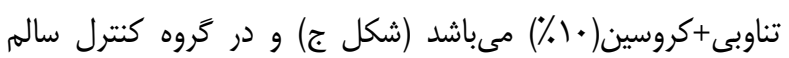

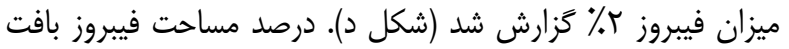

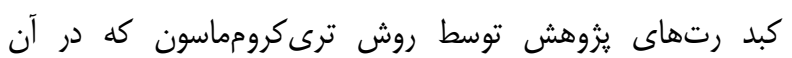

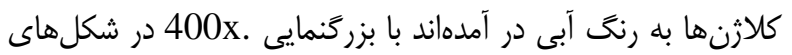
زير قابل مشاهده مىباشد.

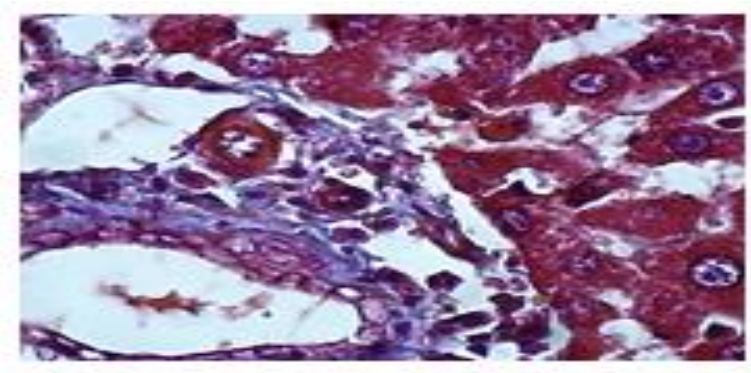

شكل ب-تروه تمرين تناوبى شديد +دوكسوروبيسين

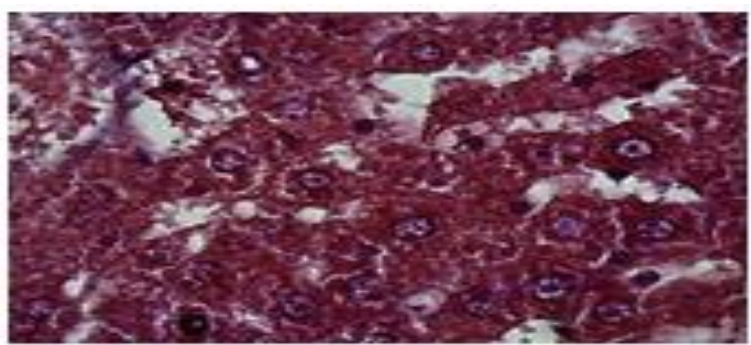

شكل ج-تروه كنترل سالم
براى مقايسه فيبروز كبدى بين گروهها نتايج روش ترى كرومماسون

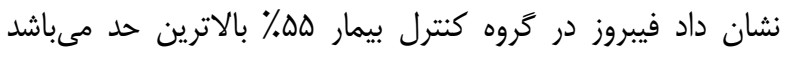

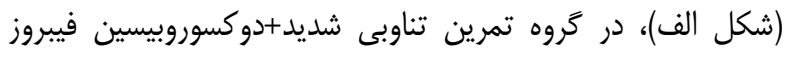

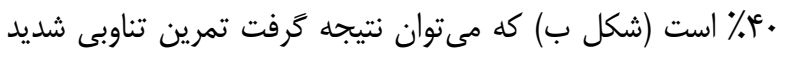

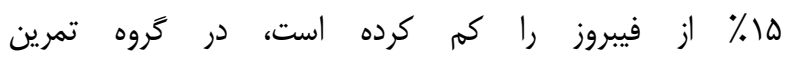

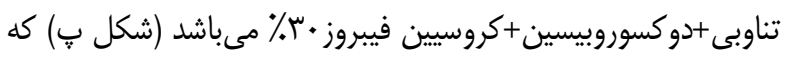

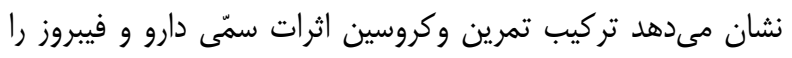

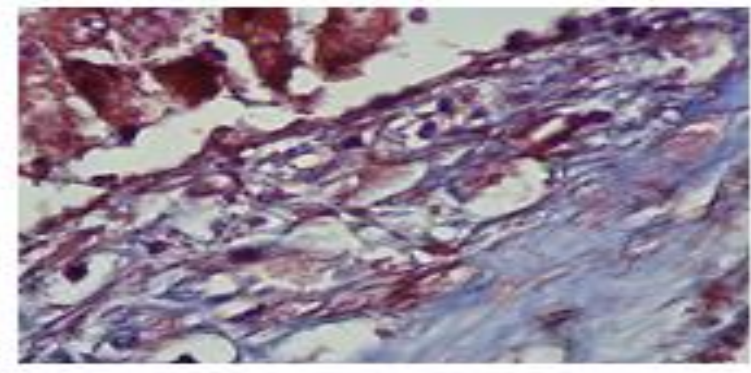

شكل الف-كروه كنترل بيمار

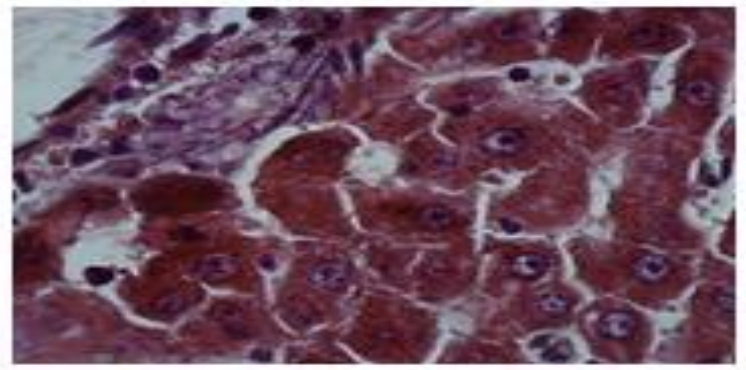

شكل ب-كروه تمرين تناوبى+دوكسوروبيسين+كروسيين

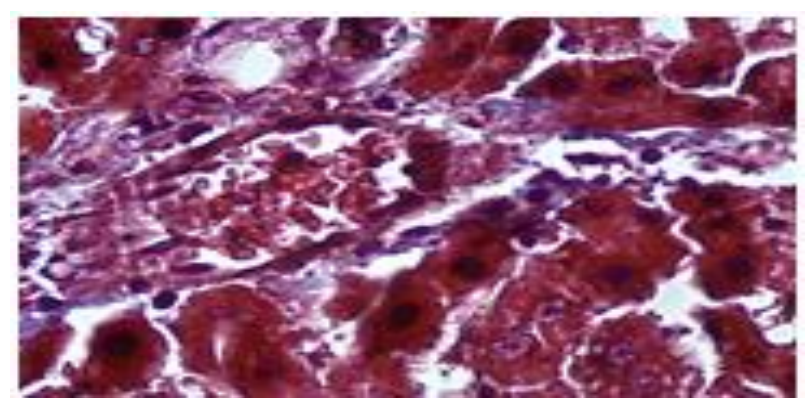

شكل د-كروه تمرين تناوبى+كروسين 
يراكسيداسيون ليييدى شده و اسيدهاى קرب غير اشباع موجود در

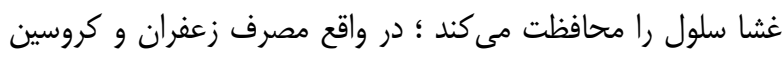
با افزايش آنتىاكسيدانها، كاهش استرس اكسيداتيو، بهبود نيمرخ

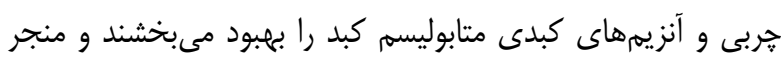

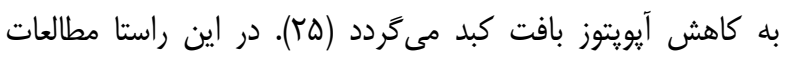
نشان دادند مصرف كروسين موجب كاهش سطوح سرمى آنزيمهاى كبدى كرديد (ع)؛؛ ناهمسو با مطالعه حاضر نتايج مطالعهاى نشان داد، مصرف mg/kg ها زعفران اثر معنىدارى بر كاهش آنزيمهاى

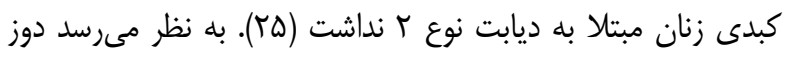

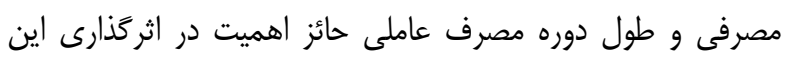
كياه دارويى باشد، نتايج مطالعه حاضر نشان داد تمرين HIIT و

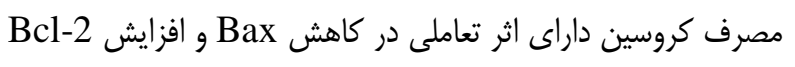

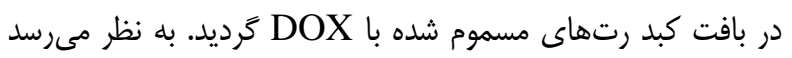

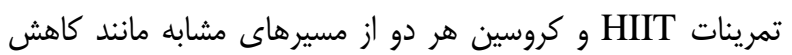
ROS

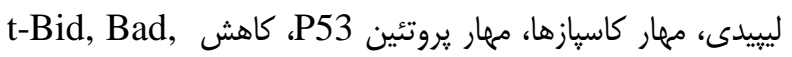

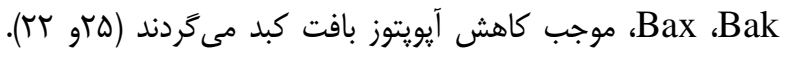
همجنين تمرينات ورزشى همراه با مصرف كروسين داراى اثرات ضد إند

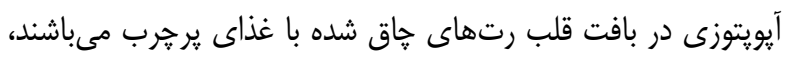

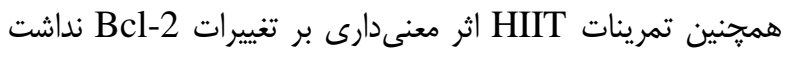

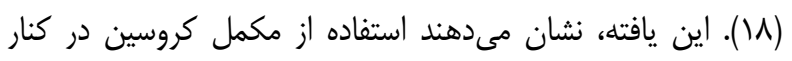
تمرينات HIIT، نسبت به انجام تمرينات تناوبى و مصرف كروسين

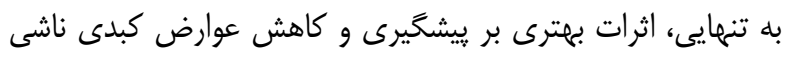

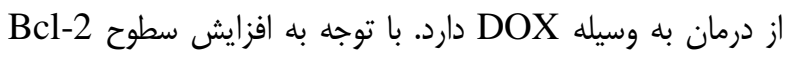
به عواملى جون استرس اكسيداتيو وابسته است و تمرينات مطالعه حاضر از نوع HIIT بود، عدم اندازهيرى سطوح فاكتورهاى ديكرى اله

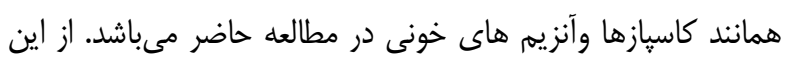

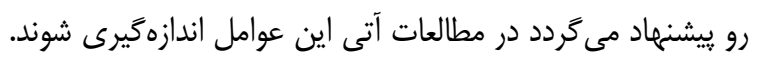

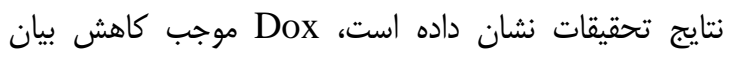
و Bcl-2 دادهاند كه داروى Dox اثرات سمّى اين دارو بر سلول مرتبط با توليد

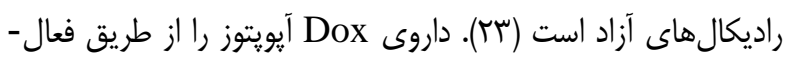

مهمترين يافته اين يزوهش، حاكى از اين بود كه استفاده از

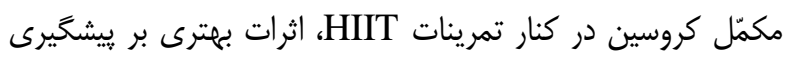

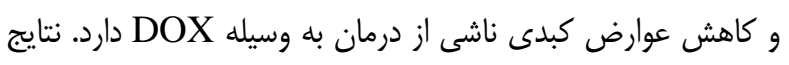

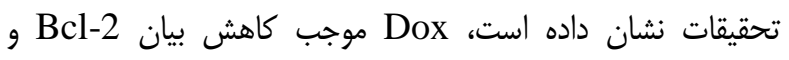

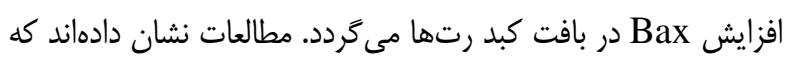
داروى Dox اثرات سمى اين دارو بر سلول مرتبط با توليد

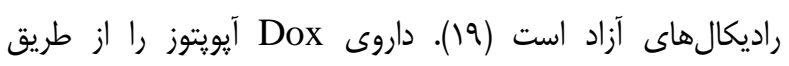

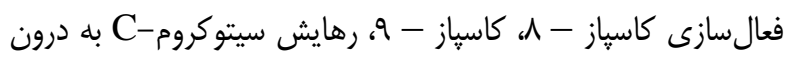

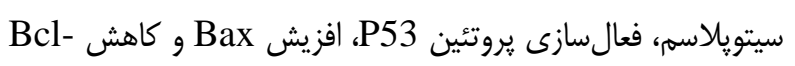

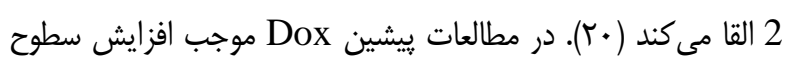

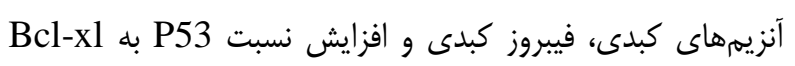

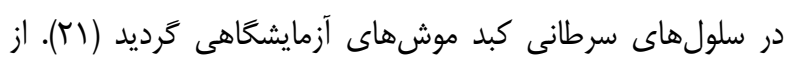

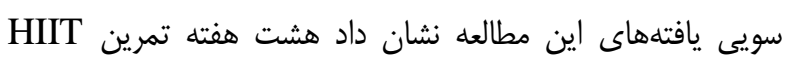

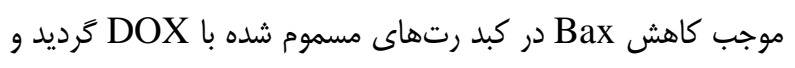

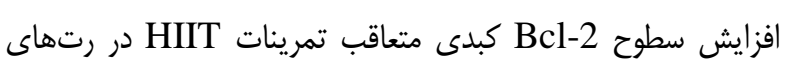

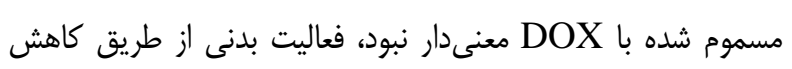
وOS

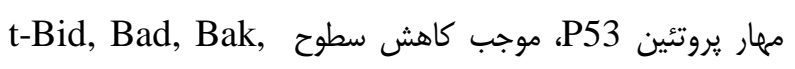

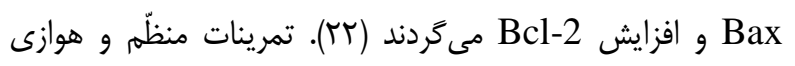

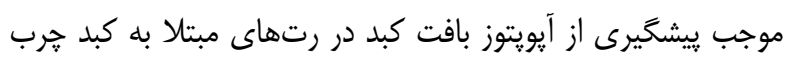

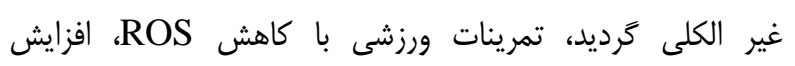

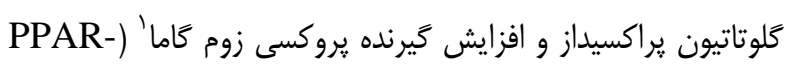

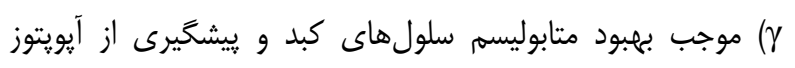

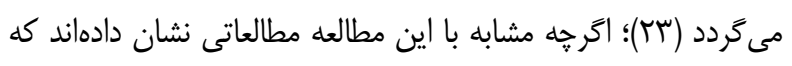

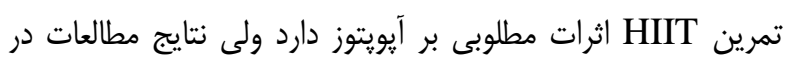

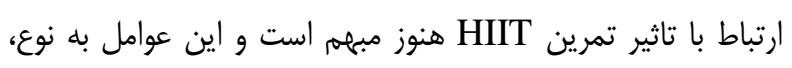
شدت، طول دوره تمرين و سطوح اوليه عوامل ييشبرنده آيويتوز

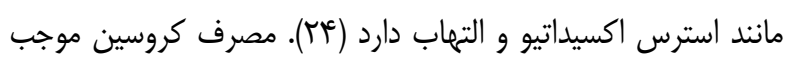

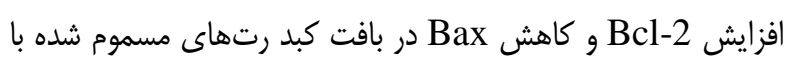

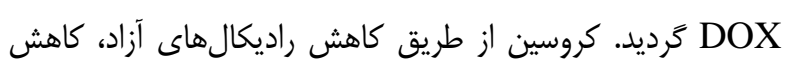

\footnotetext{
${ }^{1}$ Peroxisome Gamma (PPAR- $\gamma$ )
} 
نظر مىرسد دوز مصرفى و طول دوره مصرف عاملى حائز اهميت در اثركذارى اين كياه دارويى باشد، نتايج مطالعه حاضر نشان داد تمرين دورين و و مصرف كروسين داراى اثر تعاملى در كاهش BIIT افزاي Bcl-2 در بافت كبد رتهاى مسموم شده با DOX مر مرديد. به نظر مىرسد تمرينات HIIT و كروسين هر دو از مسيرهاى مشابه

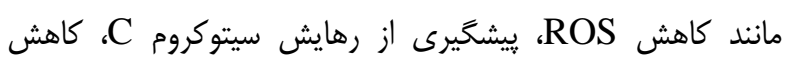

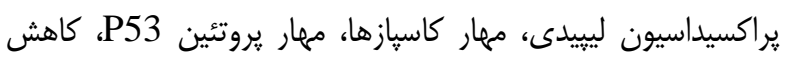
Bax ،-Bid, Bad, Bak

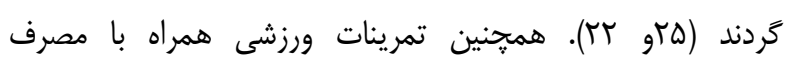
كروسين داراى اثرات ضد آيويتوزى در بافت قلب رتهاى خداى خاق شده

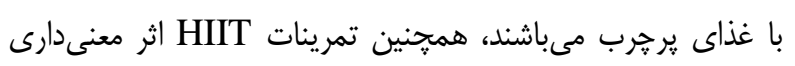

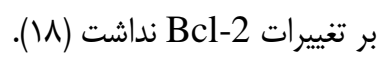

\section{نتيجه كيرى}

استفاده از مكمل كروسين در كنار تمرينات HIIT، بسيت نسبت به انجام تمرينات تناوبى و مصرف كروسين به تنهايى، اثرات بهترى بر دئر ييشيرى و كاهش عوارض كبدى ناشى از درمان به وسيله

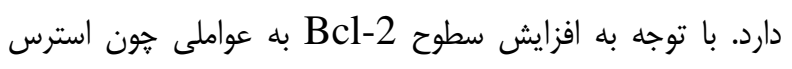

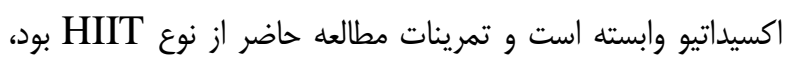
عدم اندازمخيرى سطوح فاكتورهاى ديخرى همانند كاسبازها وآنزيم

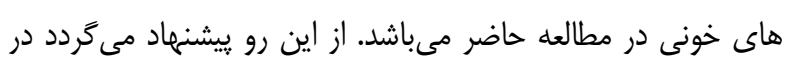

مطالعات آتى اين عوامل اندازهَيرى شوند.

\section{تقدير و تشكر}

مقاله حاضر بركَفته از پايان نامه دكترى فيزيولوزى ورزشى دانشگاه آزاد، واحد شوشتر مى باشد. نويسندكان از تمامى كاركنان

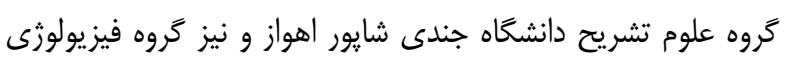

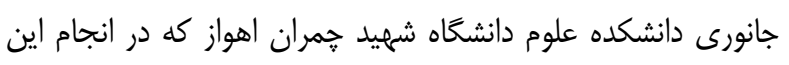

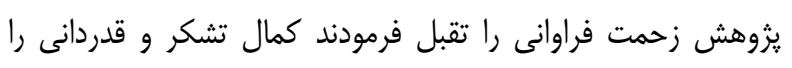
دارند.
سازى كاسياز - ^، كاسياز - 9، رهايش سيتوكروم-C به درون

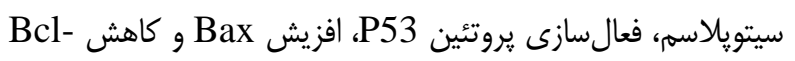

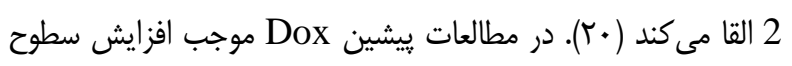

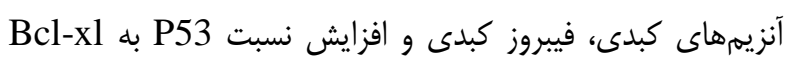

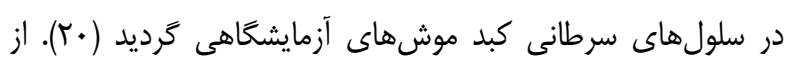

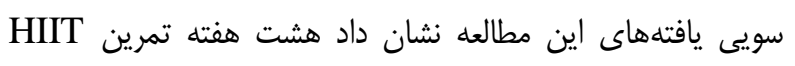

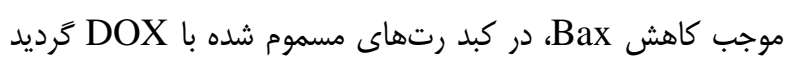

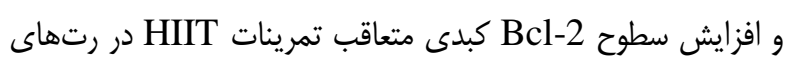

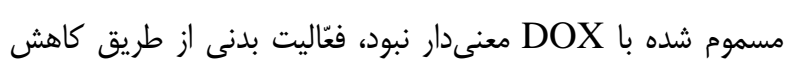

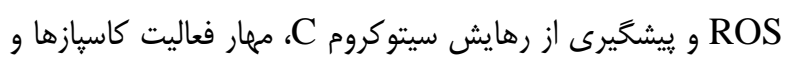

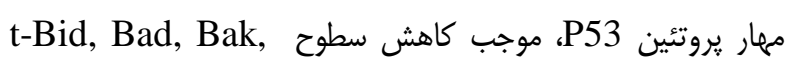

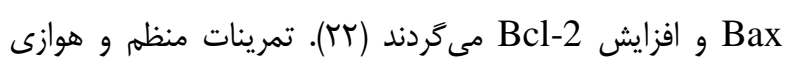

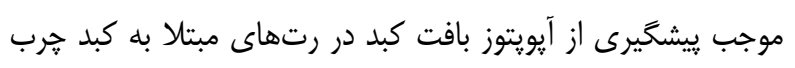

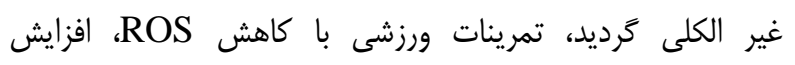

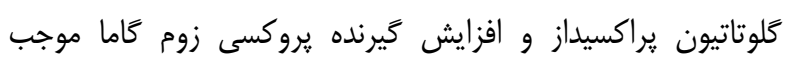

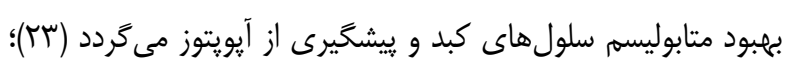

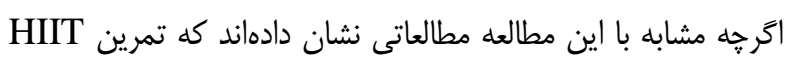

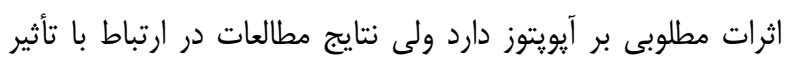

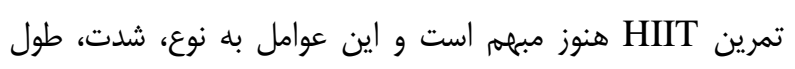

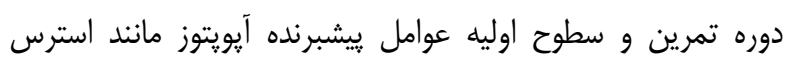

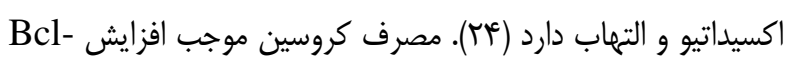

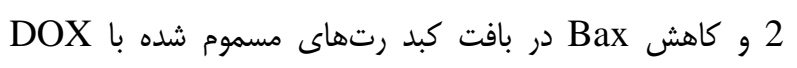

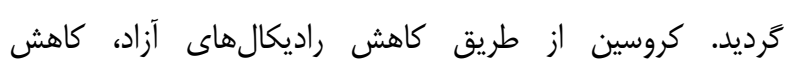

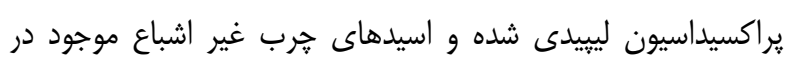

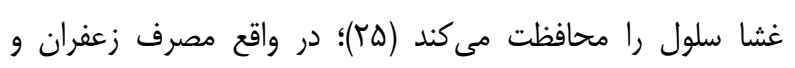
كروسين با افزايش آنتىاكسيدانها، كاهش استرس اكسيداتيو، بهبود

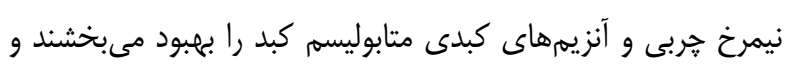

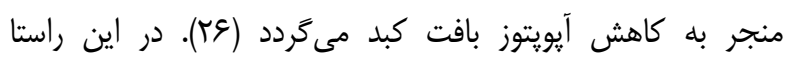

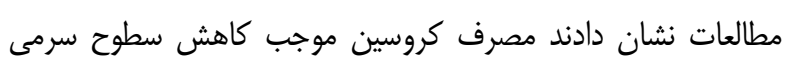

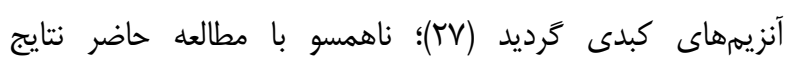

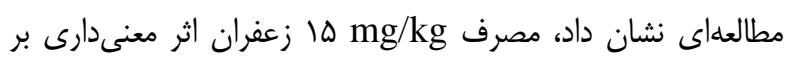

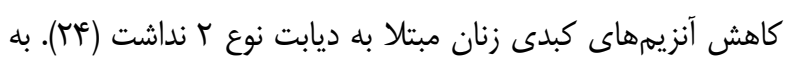




$$
\text { يزوهش حاضر وجود ندارد. }
$$

$$
\text { نويسندًان مقاله اعلام مىدارند كه هيج كَونه تضاد منافعى در }
$$

\section{منابع:}

1- Siegel RL, Miller KD, Jemal A. Cancer statistics. CA Cancer J Clin. 2015; 65(1): 5-29 DOI: 10.3322/caac.21254

2- Li M, Xiong Z-G. Ion channels as targets for cancer therapy. Int J Physiol Pathophysiol Pharmacol. 2011; 3(2): 156162.

3- Dadban Shahamat M, Dabidi Roshan V, Farazmandfar T. Effect of Continuous Aerobic Exercise on Bax/ Bcl-2 Ratio and Doxorubicin-induced Liver Toxicity in Aging model Rats. J Mazandaran Univ Med Sci. 2018; 28 (165): 36-46. [Persian]

4- Rahmani F, Najafizadeh $\mathrm{P}$, Mousavi Z, Rastegar T, Barzegar E. The protective effect of quercetin against hepatotoxicity induced by doxorubicin in male rats. Iranian J Pharmacol Ther. 2018; 16(1): 1-8.

5- Dillard CJ, Litov RE, Savin WM, Dumelin EE, Tappel AL. Effects of Exercise, Vitamin E, and Ozone on Pulmonary Function and Lipid Peroxidation. J. Appl. Physiol. Respir. Environ. Exerc. Physiol. 1978; 45(6): 927-932. DOI: 10.1152/jappl.1978.45.6.927.

6- Favaloro B, Allocati N, Graziano V, Di Ilio C, De Laurenzi V. Role of Apoptosis in disease. Aging (Albany NY). 2012 May 31; 4(5): 330-49. DOI: 10.18632/aging.100459

7- Laulier C, Lopez BS. The secret life of Bcl-2: Apoptosis-independent inhibition of DNA repair by Bcl-2 family members. Mutat Res. 2012; 751(2): 247-57. DOI: 10.1016/j.mrrev.2012.05.002

8- Ghahremani M, Azarbaijani M, Piri M, Raoufi A. Effect of Frequency Aerobic Exercise on Expression of Bcl-2 and Bax Gene in Mice With Myocardial Infarction. Armaghane-danesh. 2018; 22 (6): 781-791. [Persian]

9- TeSlaa T, Setoguchi K, Teitell MA. Mitochondria in human pluripotent stem cell apoptosis. Semin Cell Dev Biol. 2016; 52: 76-83. DOI: 10.1016/j.semcdb.2016.01.027

10- Sadat-Hoseini S K, Dabidi Roshan V. The effect of six weeks of voluntary wheel running exercise on hepatic superoxide dismutase levels and apoptosis-inducing factor after doxorubicin administration in aging model rats. Feyz. 2018; 22 (3): 267-273. [Persian]

11- Farzanegi P, Habibian M, Alinejad H. The Combined Effect of Regular Aerobic Exercise with Garlic Extract on Renal Apoptosis Regulatory Factors in Aged rats with Chronic Kidney Disease. J Arak Univ Med Sci. 2016; 19 (3): 62-70. [Persian]

12- Dadban-Shahamat, M, Dabidi-Roshan, V, \&Farazmandfar, T. The protective effect of 6 weeks of voluntary training on liver apoptosis induced by doxorubicin in aging model rats. J Isfahan Med Sch, 2018; 36(465): 14-21. [Persian]

13- Razavi BM, Hosseinzadeh H, Movassaghi AR, Imenshahidi M, Abnous K. Protective effect of crocin on diazinon induced cardiotoxicity in rats in subchronic exposure. Chem Biol Interact, 2013; 203(3): 547-55. DOI: 10.1016/j.cbi.2013.03.010

14- Srivastava R, Ahmed H, Dixit R, Saraf S. Crocus sativus L.: a comprehensive review. Pharmacogn Rev. 2010; 4(8): 200-208. DOI: 10.4103/0973-7847.70919

15- Chen S, Zhao S, Wang X, Zhang L, Jiang E, Gu Y,et al. Crocin inhibits cell proliferation and enhances cisplatin and pemetrexedchemosensitivity in lung cancer cells. TLCR, Transl Lung Cancer Res, 2015; 4(6): 775-783. DOI: 10.3978/j.issn.2218-6751.2015.11.03

16- Hassanpour G, Nikbakht H, Azarbayjani M, Shakeri N, Abednazari H. The Effect of Interval and Continued Trainings with Crocin on Apoptotic Markers in the Heart Tissue of High-Fat Diet and Streptozotocin Induced Type 2 Diabetic Rats. Rep Health Care, 2017; 3(3): 58-70 
17- Rezaei R, Nurshahi M, Bigdeli M. R, Khodagoli F, A H. Effect of eight weeks of continuous and periodic aerobic training on VEGF-A and VEGFR-2 levels of male brain Wistar rats. J Sports Exerc Psychol. 2015; 16: 1213-1221.

18- Elsherbiny NM, Salama MF, Said E, El-Sherbiny M, Al-Gayyar MM. Crocin protects against doxorubicin-induced myocardial toxicity in rats through down-regulation of inflammatory and apoptic pathways. Chem Biol Interact, 2016; 247: 39-48 DOI: 10.1016/j.cbi.2016.01.014

19- Chicco AJ, Hydock DS, Schneider CM, Hayward R. Low intensity exercise training during doxorubicin treatment protects against cardiotoxicity. J ApplPhysiol (1985). 2006; 100(2): 519-27. DOI: 10.1152/japplphysiol.00148.2005

20- Wang G, Zhang J, Liu L, Sharma S, Dong Q. Quercetin potentiates doxorubicin mediated antitumor effects against liver cancer through p53/Bcl-xl. PloS one. 2012; 7(12): e51764. DOI: 10.1371/journal.pone.0051764

21- Szántó M, Rutkai I, Hegedus C, Czikora A, Rózsahegyi M. Poly (ADP-ribose) polymerase-2 depletion reduces doxorubicin-induced damage through SIRT1 induction. Cardiovasc Res. 2011; 92: 430-438. DOI: $10.1093 / \mathrm{cvr} / \mathrm{cvr} 246$

22- Llambi F, Green DR. Apoptosis and oncogenesis: give and take in the BCL-2 family. Curr Opin Genet Dev. 2011; 21(1): 12-20. DOI: 10.1016/j.gde.2010.12.001

23- Razavi Majd Z, Matin Homaee H, Azarbayjani M A, Farzanegi P. Effects of Concurrent Regular Aerobic Training and Garlic Extract on Cardiac Tissue Apoptosis Markers in Aged Rats with Chronic Kidney Disease. J Med Plant Res. 2017; 2(62): 46-54. [Persian]

24- Farzanegi P, Dana A, Ebrahimpoor Z, Asadi M, Azarbayjani M A. Mechanisms of beneficial effects of exercise training on non-alcoholic fatty liver disease (NAFLD): Roles of oxidative stress and inflammation. Eur J Sport Sci. 2019; 19(7): 994-1003. DOI: 10.1080/17461391.2019.1571114.

25- Barra N G, Fan I Y, Gillen J B, Chew M, Marcinko K, Steinberg G R, et al. High intensity interval training increases natural killer cell number and function in obese breast cancer-challenged mice and obese women. J Cancer Prev. 2017; 22(4), 260. DOI: 10.15430/JCP.2017.22.4.260.

26- Milajerdi A, Jazayeri S, Hashemzadeh N, Shirzadi E, Derakhshan Z, Djazayeri A, et al. The effect of saffron (Crocus sativus L.) hydroalcoholic extract on metabolic control in type 2 diabetes mellitus: A triple-blinded randomized clinical trial. J Res Med Sci. 2018; 23: 16. DOI: 10.4103/jrms.JRMS_286_17

27- Huang H Y, Chen Y C, Wang P C, Tsai M A, Yeh S C, Liang H J, et al. Efficacy of a formalin-inactivated vaccine against Streptococcus iniae infection in the farmed grouper Epinepheluscoioides by intraperitoneal immunization. Vaccine. 2014; 32(51): 7014-7020. DOI: 10.1016/j.vaccine.2014.08.039 